\title{
EMPLOYABILITY COMPETENCIES OF GRADUATING STUDENTS IN A PRIVATE College IN TAgUig City
}

\section{Marlon B. Raquel ${ }^{\star}$}

College of Business Adminstration and Accountancy

The Fisher Valley College

Philippines

\section{Beryl T. Carloto}

College of Business Adminstration and Accountancy

The Fisher Valley College

Philippines

\section{Henry B. Raquel}

College of Business Adminstration and Accountancy

The Fisher Valley College

Philippines

\section{Melven B. Raquel}

College of Business Adminstration and Accountancy

The Fisher Valley College

Philippines

*Corrosponding author's Email: raquel.marlon@yahoo.com

Author's Biography

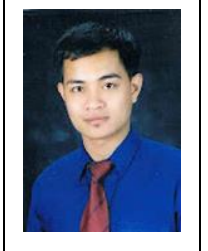

Marlon B. Raquel is currently working as the Department Head of the College of Business Administration and Accountancy at The Fisher Valley College, Taguig City, Philippines. He is also an Assistant Professor III at Taguig City University, a government university, teaching graduate courses in the Master in Business Administration (MBA) program of the Graduate School. He has presented several researches in the Philippines, Thailand, Malaysia, Indonesia, and Vietnam. Prof. Raquel is an alumnus of the University of the Philippines. His research focus includes consumer behavior, youth employment, entrepreneurship, among others. 


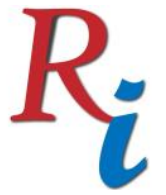

\section{Asia Proceedings of Social Sciences \\ (APSS) \\ www.readersinsight.net/APSS}

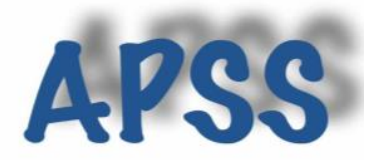

\section{Re se a r ch H i g h I g h t s}

The top most important skills identified in order to get hired in companies are communication skills and entrepreneurial skills. These are followed by critical thinking skills, problemsolving skills, information technology skills, and human relations skills. Universities should ensure that graduating students are well-equipped with the ability to communicate clearly and effectively to be able to succeed in their students' chosen professions. Schools should also inculcate the importance of love for God and perseverance and hard work as these values help future professionals in meeting the demands of business environment which are fastpaced, very rigorous and volatile. While graduating students perceived themselves as very competent in all areas of employability, it is noteworthy to note that their competency skills are relatively low compared to the levels of importance on these skills which suggest that higher educational institutions in the Philippines should continuously provide opportunities for them to enhance these competencies.

\section{Research Objectives}

The present study aimed to analyze the level of competencies of graduating students in their employability. Specifically, it sought answers to the following questions:

1. What is the socio-demographic profile of the graduating students by selected background characteristics?

2. What competencies are considered important in gaining employment after graduation as perceived by the graduating students?

3. What are the work-related values which are considered important in gaining employment?

4. To what extent do graduating students consider themselves as competent in different areas of employability?

\section{Methodology}

This study utilized a descriptive, quantitative research design. Survey questionnaires were distributed to 320 graduating students for the $2^{\text {nd }}$ Semester, A.Y. 2018-2019 in a private higher educational institution in Taguig City, Philippines with $95.24 \%$ response rate. Fivepoint Likert scale items were used to assess the competency levels of employability of the students. Frequencies, percentage distributions, weighted means, adjectival interpretations, and ranks were used in the study.

\section{Results}

About $73.8 \%$ of the respondents belong to ages 18 to 21 . There are more males $(52.4 \%)$ than their counterparts $(47.6 \%)$. Of the total number of respondents, $94.5 \%$ are single and $80.9 \%$ belong to Roman Catholic Church. Students are taking up business administration and accountancy $(35.3 \%)$, hotel and restaurant management $(26.9 \%)$, information technology (24.3\%), and secondary and elementary education (13.6\%). About $83.2 \%$ have monthly family incomes of P30,000 and below. One in every five students is currently working.

The service sector is the top choice of future professionals, followed by academe or teaching, banking and finance, and human resources. About $60 \%$ wanted to work in the government after graduation. About $45.0 \%$ of the respondents reported that there are family members who 


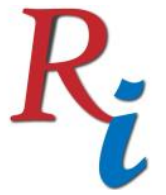

\section{Asia Proceedings of Social Sciences (APSS) \\ www.readersinsight.net/APSS}

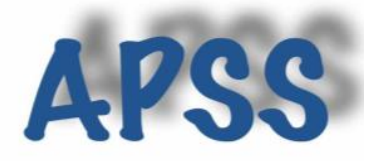

are also studying in the same institution. About $80.6 \%$ will look for jobs immediately after graduation.

The top competencies which are considered important in order to get hired are communication skills $(55.3 \%)$ and entrepreneurial skills $(19.4 \%)$. The most important factors when selecting an organization for work are when these organizations provide ample opportunities for career advancement (61.2\%) and when these companies are near their residences $(19.1 \%)$. Love for God and perseverance and hard work are very important workrelated values. Overall, graduating students reported that they are very competent in all areas of employability skills.

\section{Findings}

In recent years, the government has increased the compensation and benefits of government workers which encourages professionals to join the government service. Higher educational institutions must provide trainings that would strengthen the communication skills of the students. To attract competent individuals, companies should provide opportunities for career advancement. As suggested by Kraimer, et al (2011), perceived growth opportunities may result to higher job performance.

The love for God and perseverance and hard work as most important work-related values indicate that Filipino students give prime importance on their faith in God and hard work in workplaces. Nearly nine of 10 Filipinos consider religion as vey important in their lives (Pew Research Center, 2015). Results also suggest that students are well-prepared to face the rigors of the corporate world as they reported high levels of competencies in all areas of employability, namely, problem-solving and analytic, learning, personal organization and management, creativity, innovation and change, and personal strengths. Lee and Bruvold (2003) claimed that equipping employees with competencies, new knowledge and skills means investment in career development that can enable them to accept new challenges outside or within the organization.

\section{References}

Bagaoisan, A. J. (2015). Why Filipinos are among world's most religious. In Global Attitudes Survey Pew Research Center. Retrieved at https://news.abs-cbn.com/focus/01/07/16/why-filipinos-are-amongworlds-most-religious

Baring, R. \& Cacho, R. (2015). Contemporary engagements and challenges for Catholic religious education in Southeast Asia. In Global Perspectives on Catholic Religious Education in Schools. Edited by Michael Buchanan and Adrian Gellel. Basel: Springer Publishing, pp. 143-53.

Lee, C. H., \& Bruvold, N. T. (2003). Creating value for employees: investment in employee development. The International Journal of Human Resource Management, 14(6), 981-1000.

Orence, A. \& Laguador, J.M. (2013). Employability of Maritime Graduates of Lyceum of the Philippines University from 2007-2011, International Journal of Research in Social Science, 3(3): 142-157.

Reave, L. (2005). Spiritual values and practices related to leadership effectiveness. The Leadership Quarterly, $16(5), 655-687$. 